\title{
MEASURES TAKEN AGAINST WATER POLLUTION IN THE FOOD PROCESSING INDUSTRY
}

\author{
L. C. GILDE
}

Campbell Soup Co., Campbell Place, Camden, New Jersey 08066, USA

\begin{abstract}
The food processing industry is involved with the total environment from the farm to the consumer. Particular emphasis is placed upon the need for precise sanitary control in order to assure that water reuse and reclamation programmes provide maximum protection for the safety and quality of the product. Various means to minimise water use such as counter-flow systems, temperature control, $\mathrm{pH}$ control, turbidity control and chlorination control are reviewed. Design of equipment is a factor in effective sanitary conditions and proper water utilisation.

Abatement of waste water pollution load must start in the plant and be integrated with proper water utilization technique to reduce waste. Wherever possible, waste solids should be handled dry and not flumed. Consideration should be given to segregation of particularly concentrated waste streams within a plant for separate treatment in order to reduce overall treatment costs or surcharges from the municipalities.

Interesting concepts for utilizing the land as a sink for treatment processes and solid waste disposal are discussed. A new concept of spray irrigation by overland flow wherein the waste water is spread in a thin sheet to have a good interaction zone with soil humus and the microbiological activity of the soil organisms purify to achieve 99 per cent BOD reduction, in a travel of approximately 225 feet. This is accomplished on relatively impervious soils with slopes of approximately two to six per cent.

Solid waste disposal is a source of much concern now and especially for the future. There is an interdependence with this problem between the grower, the processor and the consumer. More research work has to be conducted to reclaim the nutritional value in food wastes and to avoid unsanitary conditions both on the farm, at processing plants, and in municipalities. There is a need for attacking these problems on a regional basis and the possibility of centralising recovery areas of wastes for by-product reclamation purposes in order to achieve a more economical, feasible programme may be necessary, especially for smaller processors. Our goal should be the elimination of transporting any waste solids in any form in the various steps from the farm to the processor to the consumer. Ideally, only perfect crops without culls, trims or rejects should reach the food processor. In turn, the food processor should develop convenience foods in edible packages, thus eliminating solids disposal at the home.
\end{abstract}

\section{INTRODUCTION}

A food processing industry is involved with the total environment from the farm to the customer. It is dependent upon good quality water and therefore 


\section{C. GILDE}

is aware of water as a commodity which must be used as efficiently and effectively as possible. Water is absolutely necessary for many steps in the food processing industry. At present, there is no economical substitute. Consequently, water conservation and water reuse are necessary and most of the industry practices this in order to conserve this vital natural resource and reduce operating costs. By practising conservation and reuse, the amount of liquid waste is reduced as is also the pollution potential from food processing operations.

\section{REQUIREMENTS, REUSE AND SEGREGATION}

The food industry as a whole uses prodigious quantities of water, but this is not a consumptive use. The canning industry in the United States requires approximately 40 billion gallons of water to pack approximately 800 million cases of food each year. The water is required for fluming, washing, blanching, pasteurizing, cleaning of process equipment, and cooling of finished product.

The quality of water that touches the product is of extreme importance. At Campbell Soup Company, water purchased from a community or city always goes through further treatment such as carbon filtration in order to assure complete freedom from taste and odour. A uniform standard of water is essential in order to be assured that the product made in any state in the United States, and, in fact, any country in the world, has the same quality and taste.

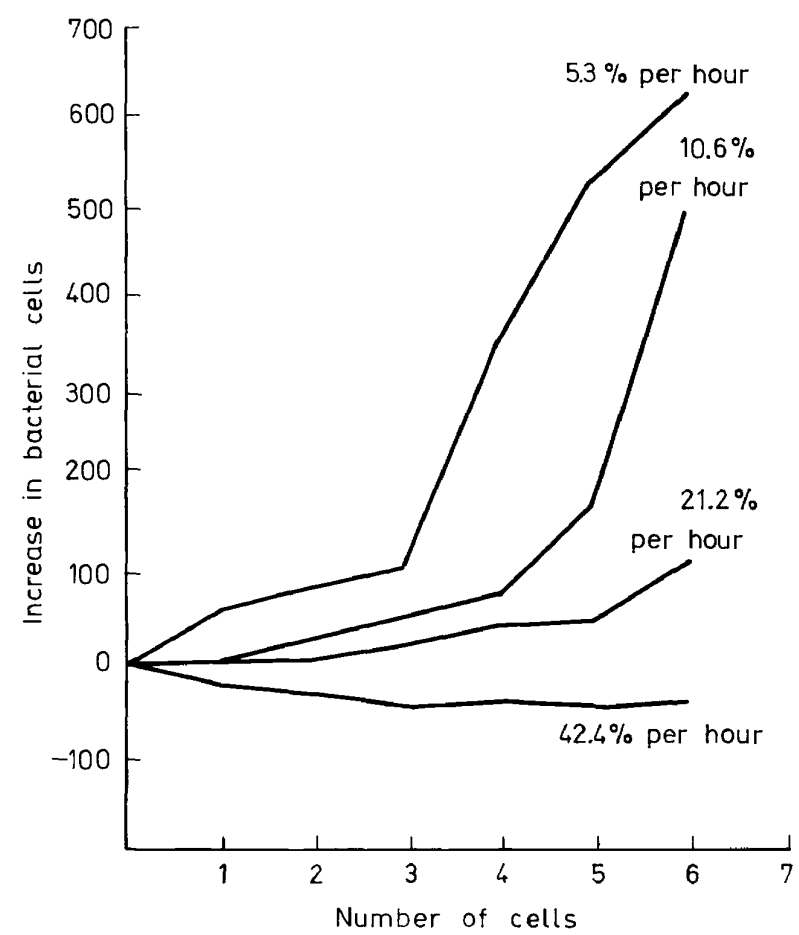

Figure 1. Comparison of water replacement on the growth of mesophilic bacteria at $90^{\circ} \mathrm{F}$. 


\section{MEASURES AGAINST WATER POLLUTION IN FOOD INDUSTRY}

Historically, little consideration was given to the reuse of water both because of its abundance and also because reuse was considered to be hazardous because of the problems of bacterial contamination with subsequent spoilage of cans. An example of water use to maintain sanitary conditions is shown in Figure 1 where the relationship of water exchange to bacteriological conditions shows that unless 40 per cent of the water is exchanged each hour, the growth rate of bacteriological organisms is extremely high. Of course, in order to overcome this, other means of control must be used such as chlorination. By development of new techniques such as chlorination, reuse of water could be considered, but even so, quality is the most essential factor and therefore sanitary conditions of operation are the controlling criteria for the reuse of water. Much study and research are required to ascertain the limitations of chlorine as a benefit in order to prevent bacterial problems in the final product. The National Canners Association has set up four principal conditions governing the use of reclaimed waters in contact with food products. They are as follows: (1) that the water be free of microorganisms of public health significance, (2) that the water contain no chemicals in concentrations toxic or otherwise harmful to man, (3) that the water be free of any materials or compounds which could impart discolouration, off-flavour, or odours to the product or otherwise adversely affect its quality, and (4) that the appearance and content of the water be acceptable from an aesthetic viewpoint.

Water conservation can be achieved through the use of counter-flow reuse systems. Such a system is shown in Figure 2 outlining a counter-flow system for reuse of water in a pea cannery. At the top of the system, fresh water is

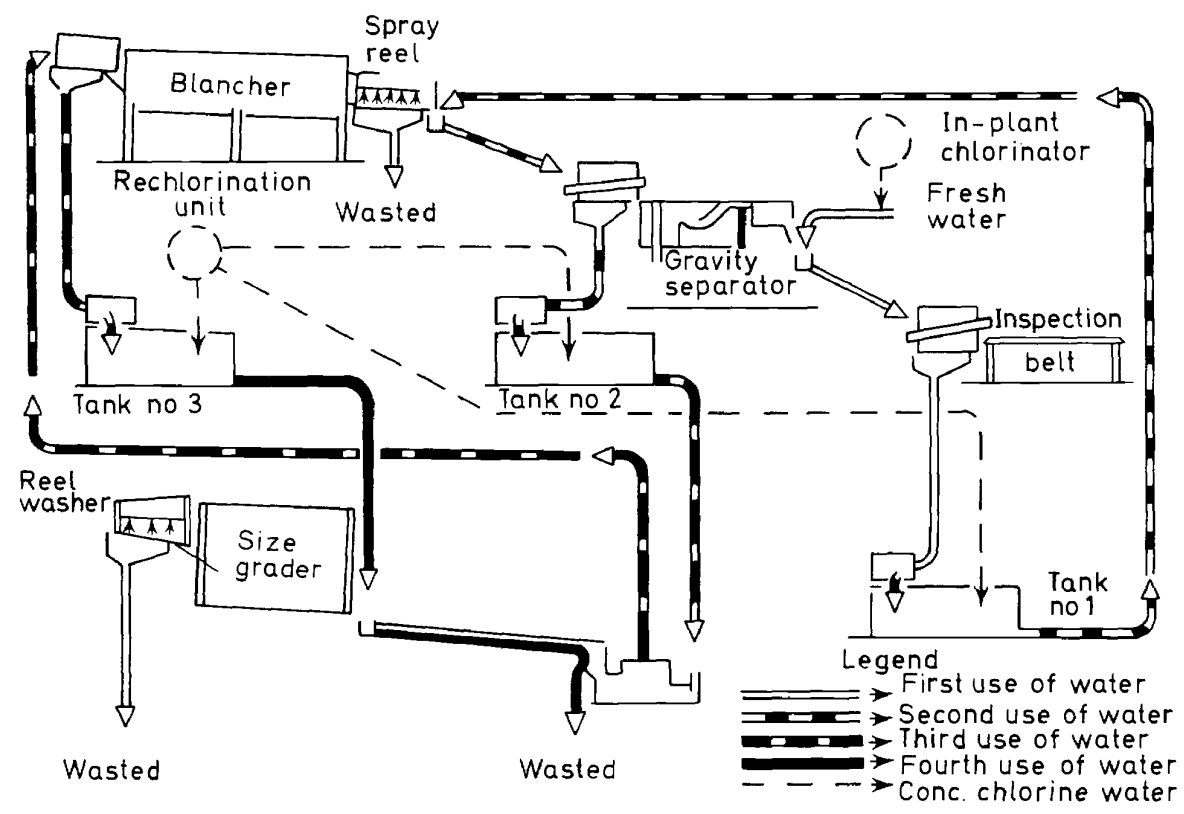

Figure 2. Diagram of 4-stage counterflow system for reuse of water in a pea cannery. 


\section{C. GILDE}

used for the final product wash before the peas are canned and from this point the water is reused and carried back in successive stages for each preceding washing and fluming operation. As the water goes counter-current to the product, the washing and fluming water can become more contaminated and therefore it is extremely important, as shown in Figure 2, to add chlorine in order to maintain satisfactory sanitation conditions. At each stage, sufficient chlorine should be added to completely satisfy the chlorine demand of the organic matter in the water. With this arrangement, satisfactory bacteriological conditions should exist in each phase of the washing and fluming program. The importance of chlorination to maintain satisfactory sanitary conditions is graphically shown in Figure 3 . When chlorination was discontinued, the bacterial count more than doubled. As soon as chlorination resumed, the bacterial counts were again brought under control.

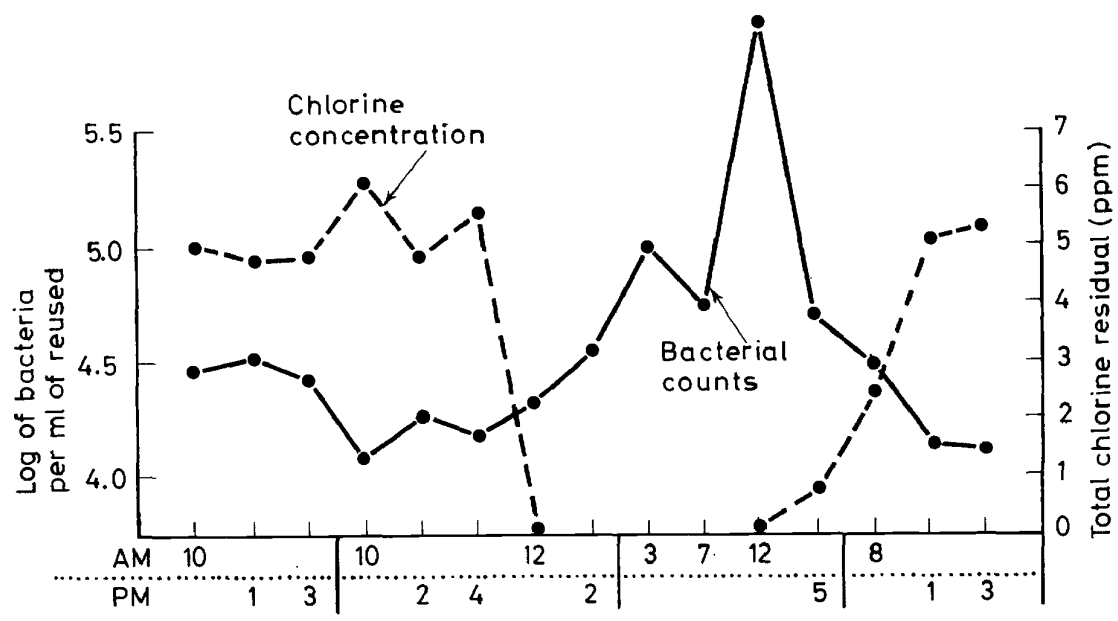

Figure 3. Effect of chlorine concentration (reused water).

Proper design of the system is not only important from the standpoint of water use and conservation but also from the standpoint of sanitary conditions. Figure 4 shows a water reuse system in which the bacteriological counts actually increase as the tomatoes move through the system. A much better system is shown in Figure 5 where the condition of the tomatoes is improved due to the use of sprays before changing from one flume system to another. Many factors determine the final effectiveness. As an example, tomatoes spray-washed on a roller belt where they are turned are almost twice as clean as the same tomatoes washed on a belt of wire mesh construction. Also, warm water is approximately 40 per cent more effective in removing contaminants as is the same volume of cold water.

Another recent development in the effective removal of contaminants has been the use of detergents. Normally, drosophila eggs are extremely difficult to remove from tomatoes with just conventional washing. These eggs are laid in fresh cracks in the fruit and during certain weather conditions become an extreme problem. It was found that water at approximately $140^{\circ} \mathrm{F}$ 
MEASURES AGAINST WATER POLLUTION IN FOOD INDUSTRY

Warm water

$120^{\circ} \mathrm{F}$

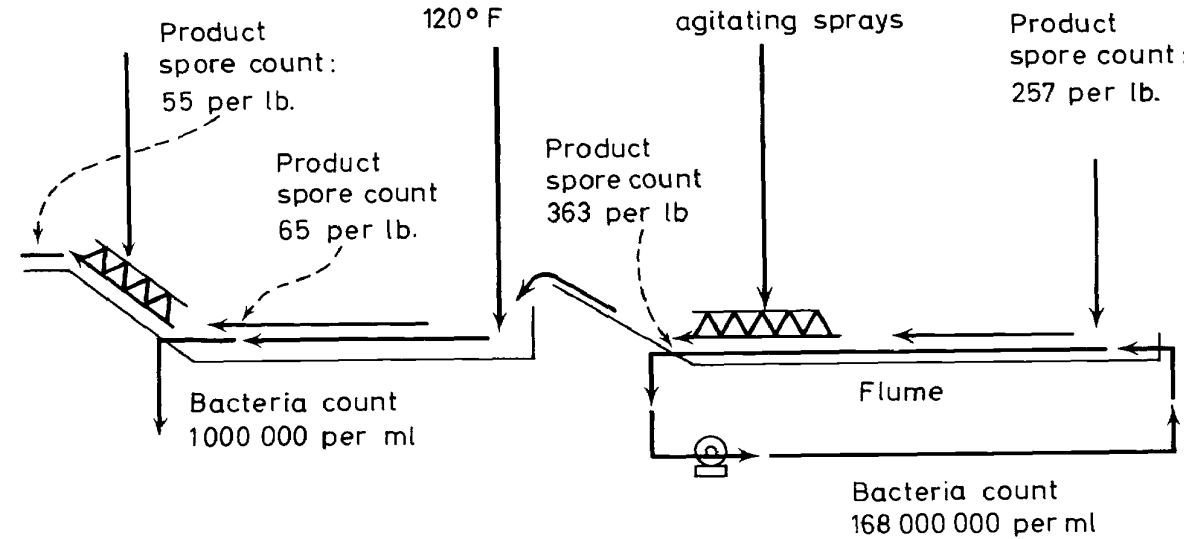

Figure 4. Reuse and recirculation of water in tomato washing and fluming. Recirculation of water in the first flume caused an increase in spore count for tomatoes leaving the flume.

containing a low-foam, highly alkaline detergent at approximately $\mathrm{pH} 12$ will remove more than 90 per cent of the eggs. Adequate spray-rinsing after the detergent wash reduced the residue to a level much lower than could be detected by any known chemical method of analysis.

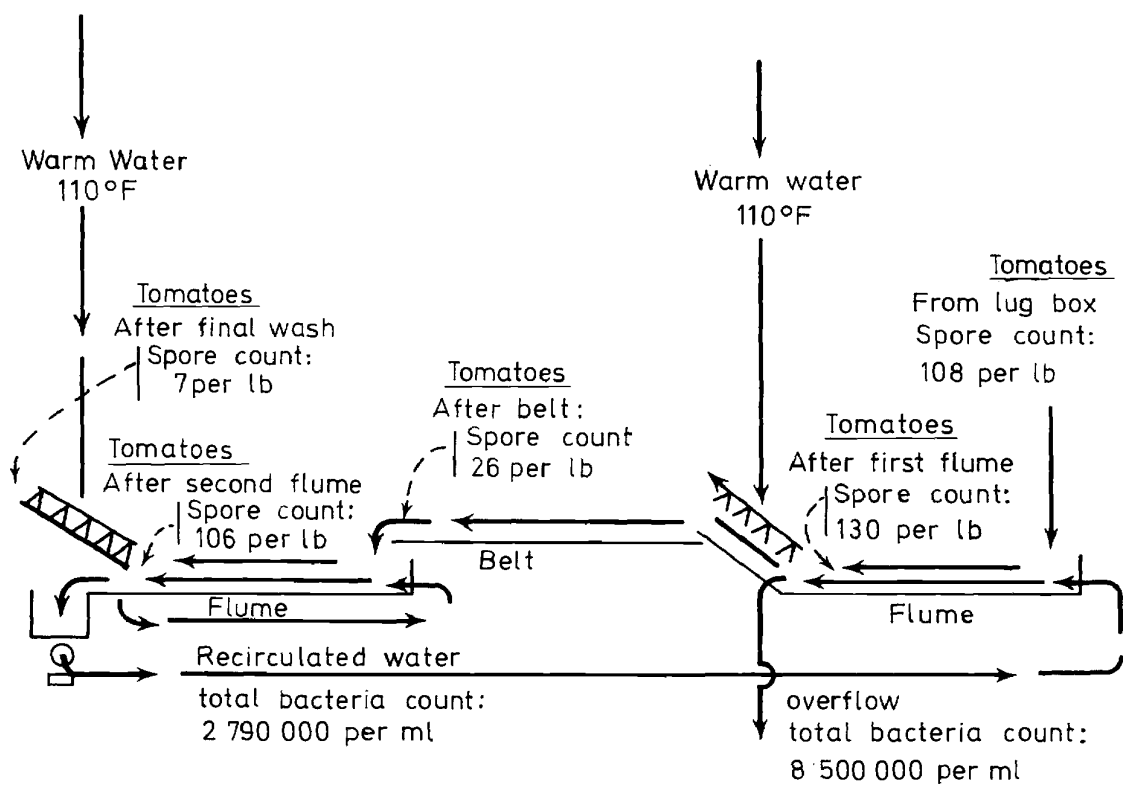

Figure 5. Recommended arrangement of flumes, sprays and water use when dumping section can be separated from remainder of washing system. 


\section{C. GILDE}

The previous paragraphs have highlighted the importance of the interrelation of process and water use. There always has been and will continue to be a delicate balance between water conservation and sanitation. There is no straightforward simple formula to obtain the least water use. Each case and each food process has to be evaluated with the equipment used in order to come up with satisfactory procedures involving water use, chlorination, and other factors such as detergents. Unfortunately, the industry is faced with counter demands. There is more and more a tendency towards bulk handling of food, which then-based on our limited knowledge today-requires seemingly larger fluming systems with more water to handle these large bulk quantities of food. It is apparent, however, that the most effective means of abating water pollution are in-plant modifications to reduce water consumption under sanitary conditions and to prevent water-conveying of solid wastes.

The discussion up to this point has been limited primarily to the fluming and washing of foods. After limited processing, such as peeling, it is frequently necessary to flume cut fruit such as peaches. This flume water is a source of large water use and a potential waste load. Recently, it has been determined that by controlling the $\mathrm{pH}$ by the addition of citric acid, it possible to reduce the water use and also have no increase in bacterial numbers. As shown in Figure 6, a pH of 4 will maintain optimum conditions with cut fruit, such as

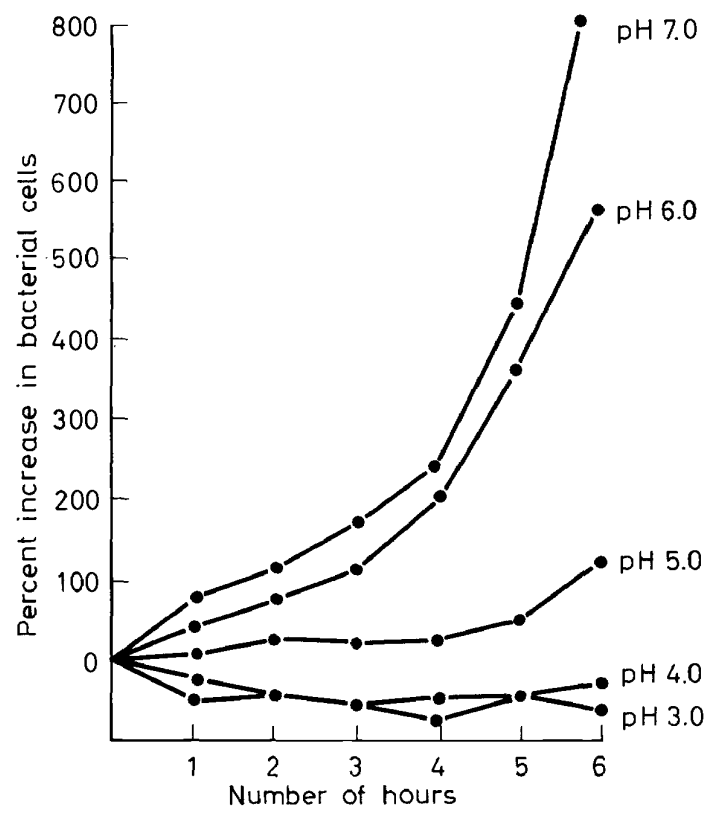

Figure 6. Effect of $\mathrm{pH}$ control on the growth of bacterial cells.

peaches. Figure 7 shows a typical system for controlling and monitoring the conveying of cut fruit to maintain a constant $\mathrm{pH}$ of 4 . The system not only reduces the total volume of water required and therefore the amount of 


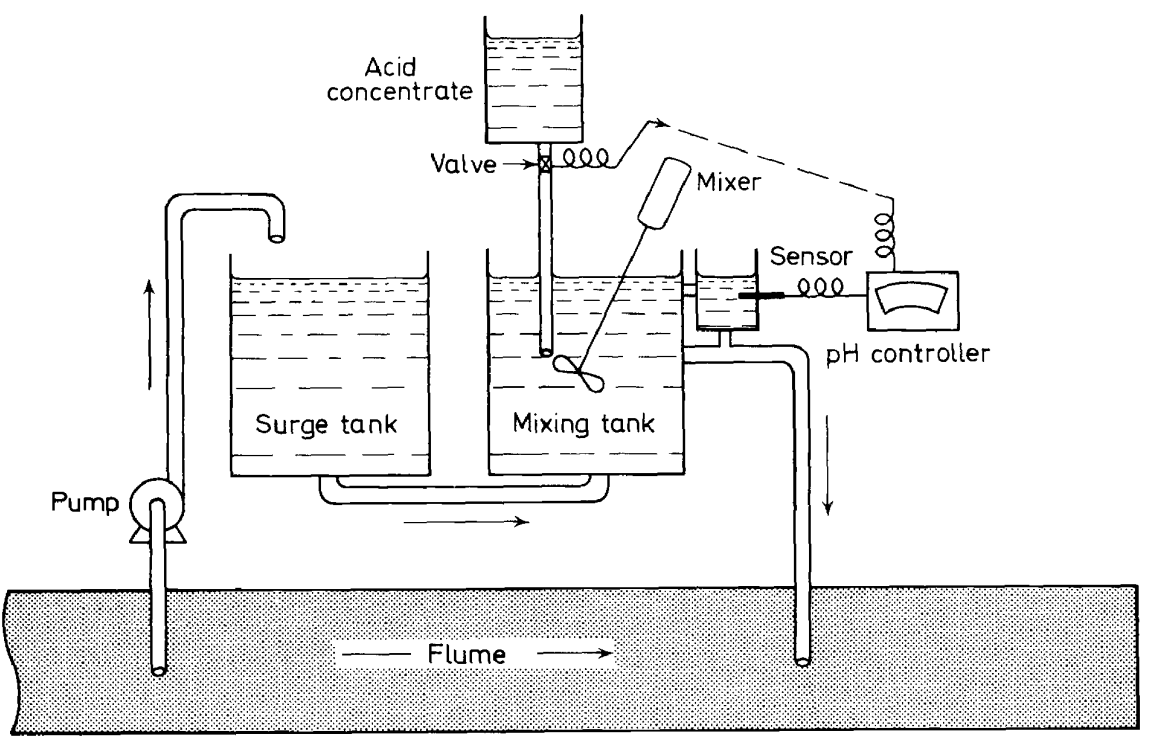

Figure 7. pH control of recirculated pumping water.

waste water discharged, but increases the product yield as a result of decrease in the loss of solids due to leaching of sugar and acids. Consequently, there is a reduction in the total pounds of organic pollutants in the waste water. Another advantage is improved flavour and colour of the canned fruit due to better retention of soluble solids.

It is not possible to cover all the concepts and ramifications inherent in various food processing industries to reduce water and at the same time maintain product quality while also reducing waste loads. Wherever possible, the food should be handled by either a mechanical belt or pneumatic dry conveying system. If possible, the food should be cooled by an air system rather than the normal water cooling system. An outstanding example of water conservation and waste reduction was described by Mr. Granville Perkins of Artichoke Industries Inc. in Castroville, California at the recent National Symposium on Food Processing Wastes in Portland, Oregon in April, 1970. This operation, over a ten year period of time while the volume of product processed increased, was able to reduce the volume of waste load from 400000 gallons per day with a BOD of $1500 \mathrm{ppm}$ to a present output of 40000 gallons per day with 1200 ppm BOD. This was accomplished by many unique systems such as using fog nozzles for wetting product in order to reduce the oxidation rather than flooding the product with sprays or fluming it in water. Pneumatic separators replaced rod reel washers. Trimming machines were redesigned to incorporate pneumatic separation at the point of cutting. At every step, where possible, waste was separated from product and handled dry. Product cooling water for the freezer line is recirculated, screened, refrigerated and used over and over. A low-pH citric acid solution minimizes bacterial buildup at the $50^{\circ} \mathrm{F}$ temperature. Blancher make-up water is held to an absolute minimum since this is the highest BOD water within the plant. 
There certainly is a need for more innovative attacks throughout the food processing industry such as has been accomplished in this plant.

The segregation of waste within a plant can be important to optimizing the least-cost approach towards waste treatment. Figure 8 shows a typical brewery and the fact that three per cent of the flow contains 59 per cent of the

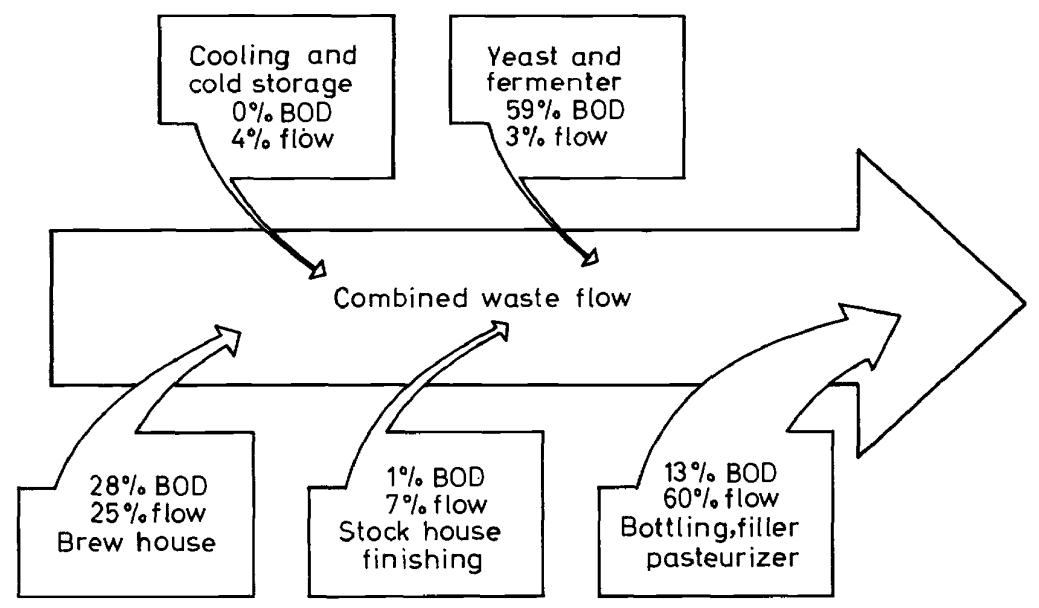

Figure 8. Source and relative strength of wastes from brewery.

BOD. In a case such as this, it is normally less expensive to treat this small flow separately rather than to mix it with the entire plant waste flow. This can be of value when a plant treats its own wastes, or in cases when it releases its waste to a municipality where surcharges might be required for highstrength waste.

\section{WASTE TREATMENT}

The National Canners Association developed Table 1 to show the different types of waste and how they can be treated. The asterisk indicates which of these methods have been studied under special research projects by the NCA. Figure 9 shows the complexity of waste treatment in a waste treatment maze and the number of decisions and types and methods of treatment for a food processing waste. There is no simple rule of thumb to guide the food processor into the most practical and economical method of treatment. Each type of system and approach may have merit, depending upon the peculiarity of the local conditions or circumstances. The food processor, if he does not have his own sanitary engineering staff, has to depend upon consulting engineers and should be sure that those whom he calls upon to perform such services have wide-spread knowledge in the area of the characteristics of food processing wastes and how they can be treated in order that he can receive through this service the most economical system possible.

Literature is well documented with most of the conventional methods of food processing waste treatment systems. For this reason, this paper will 


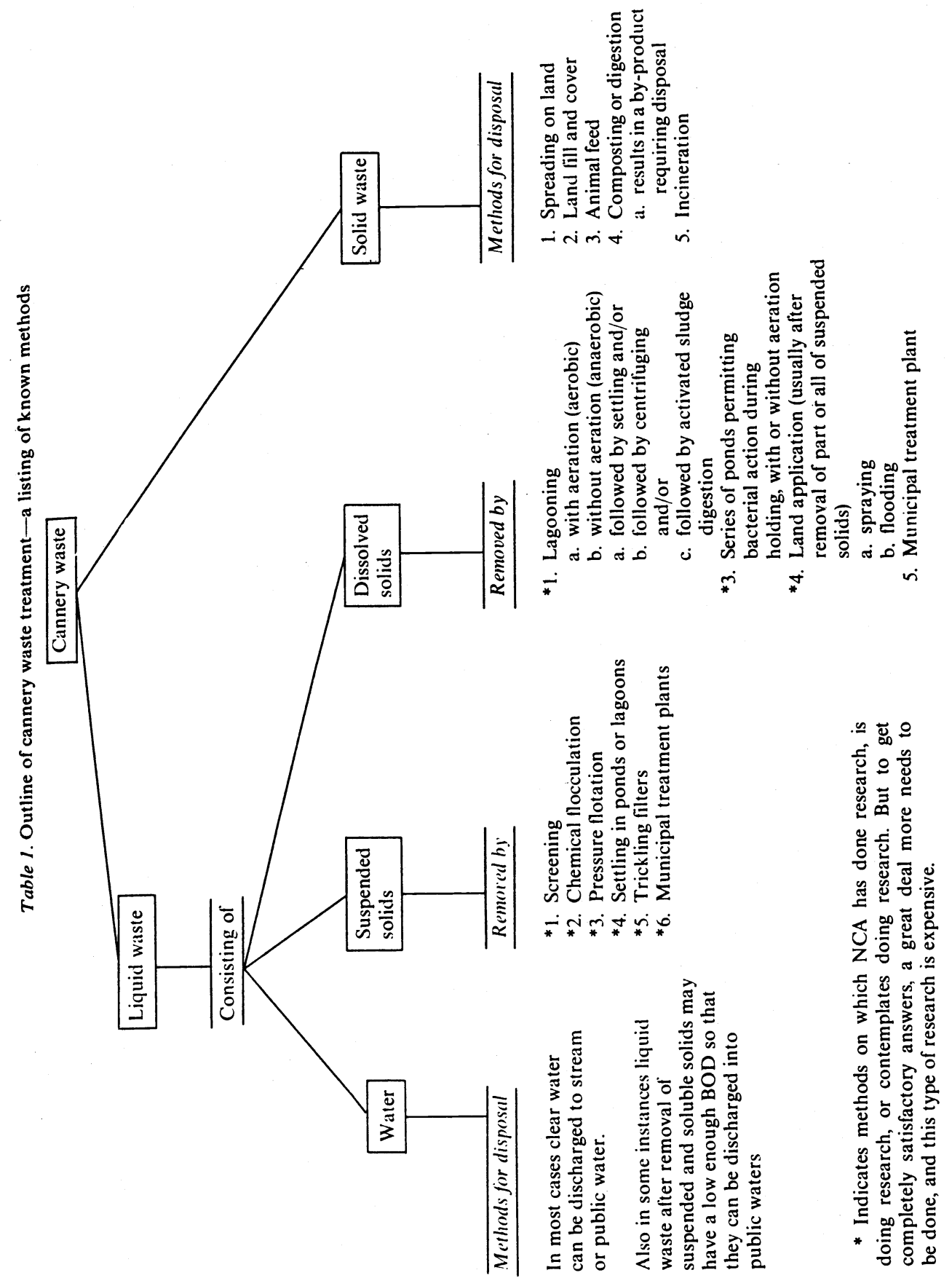


L. C. GILDE

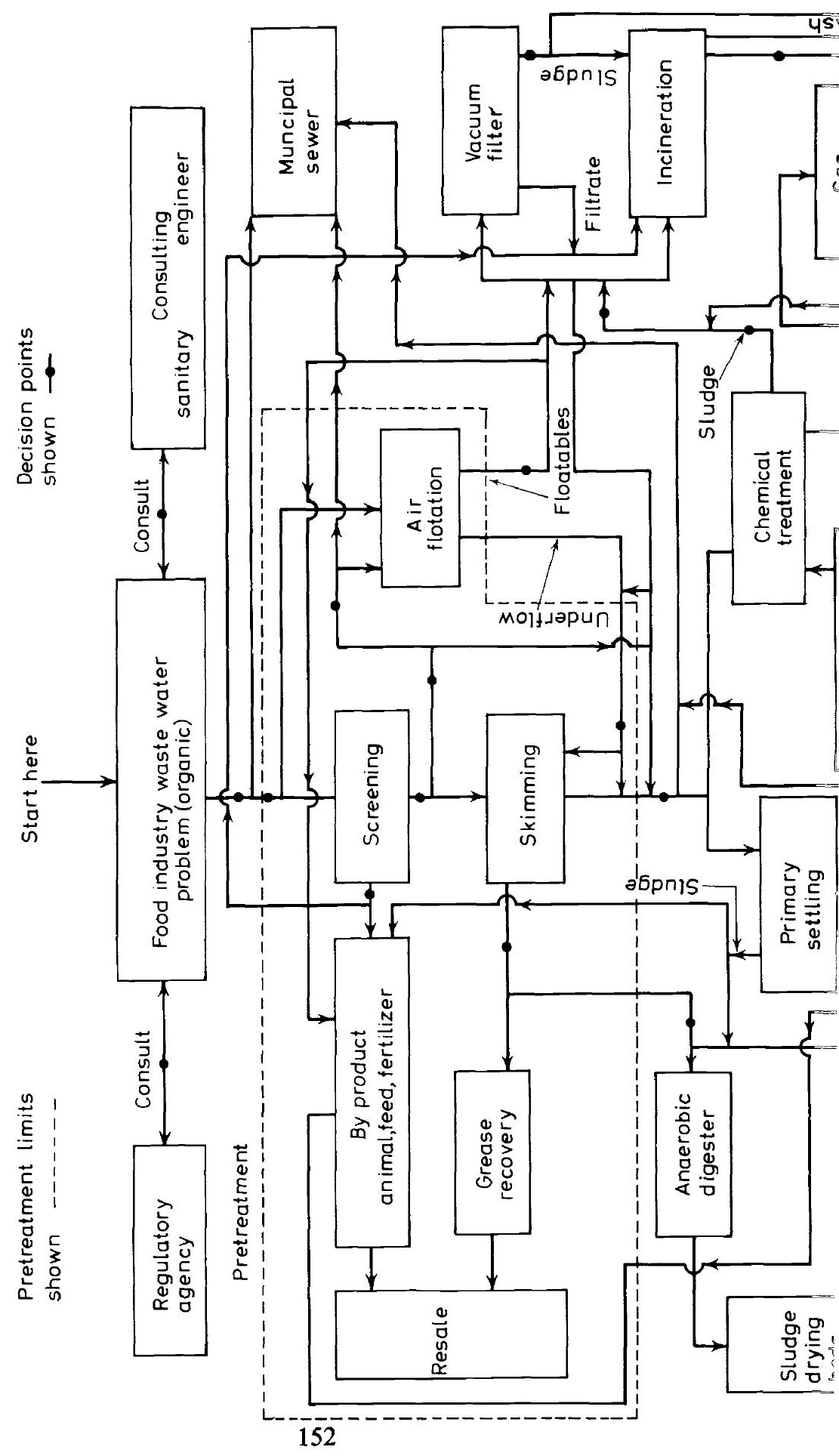



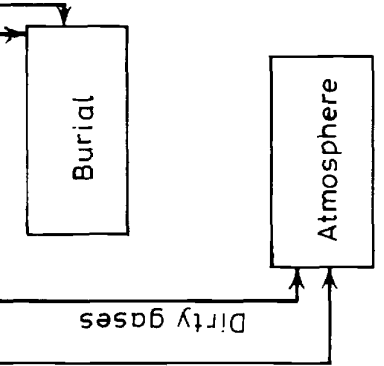

SASDE UDVIJ

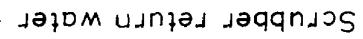

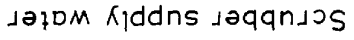

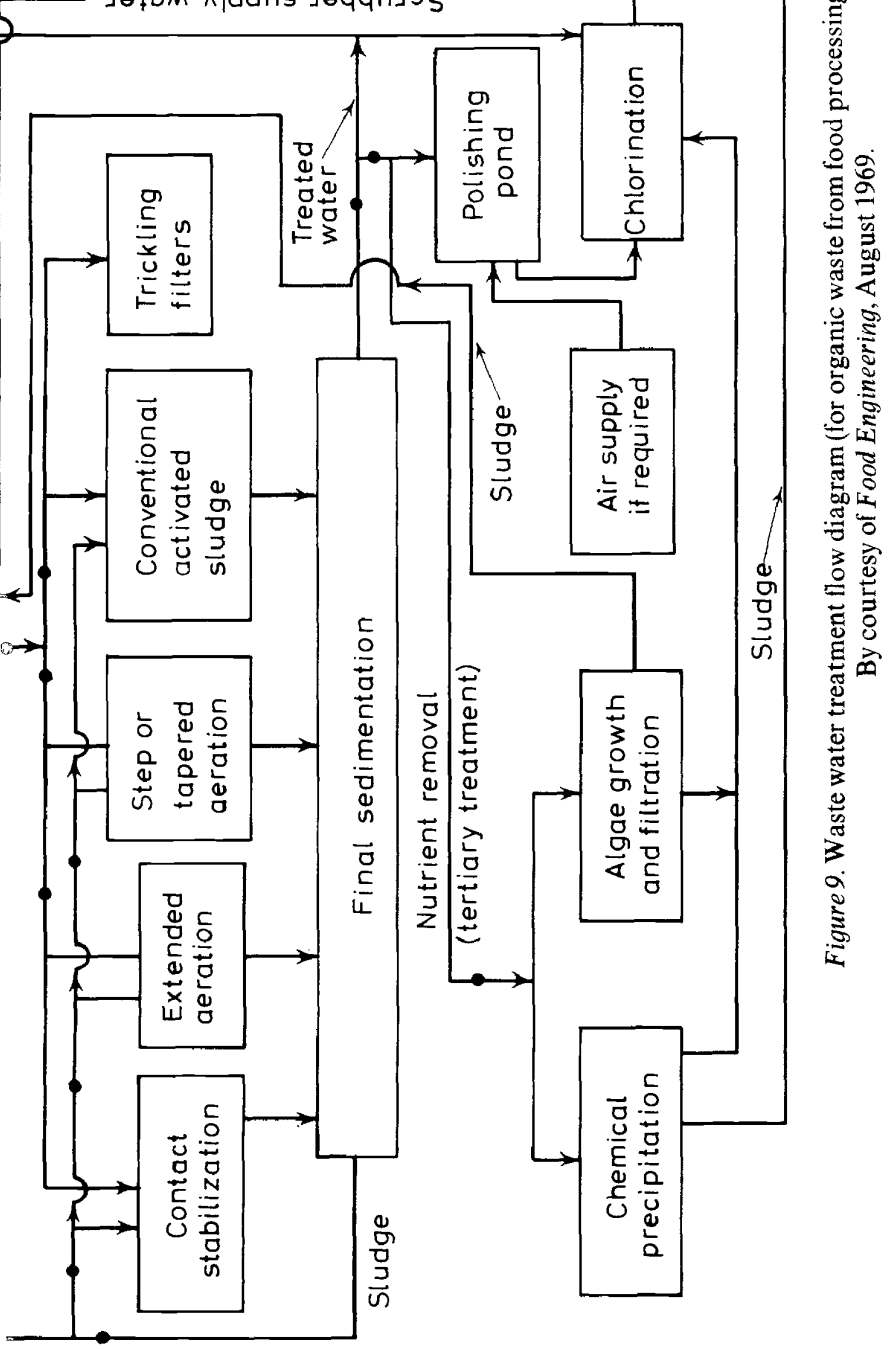




\section{C. GILDE}

cover two unique systems of food processing waste treatment utilizing the land in a return to nature's ways to achieve the equivalent of tertiary treatment. At Campbell Soup Company, we have adopted the philosophy that where food processing plants can be located in rural areas, attempts should be made to utilize the natural environment for treatment purposes.

An outstanding example of this is the Paris, Texas plant which utilizes a spray irrigation system for an overland flow filtration method to treat the waste water biologically. Waste water disposal by natural filtration encompasses a great deal more than the irrigation of waste water, and its infiltration into the soil. In this particular case, the site contained practically impervious soil and it was not possible to obtain any significant infiltration into the ground. The natural filtration process of waste treatment using the overland flow method purilies water by flowing it over the surface in a thin uniform sheet. The system is laid out on land that is contoured so that the wastes flow in a thin sheet across the surface of the land and are collected in terraces to be conducted from the field. As many as four or five sprinkler lines are laid out on a hillside, as shown on the diagram of Figure 10. The

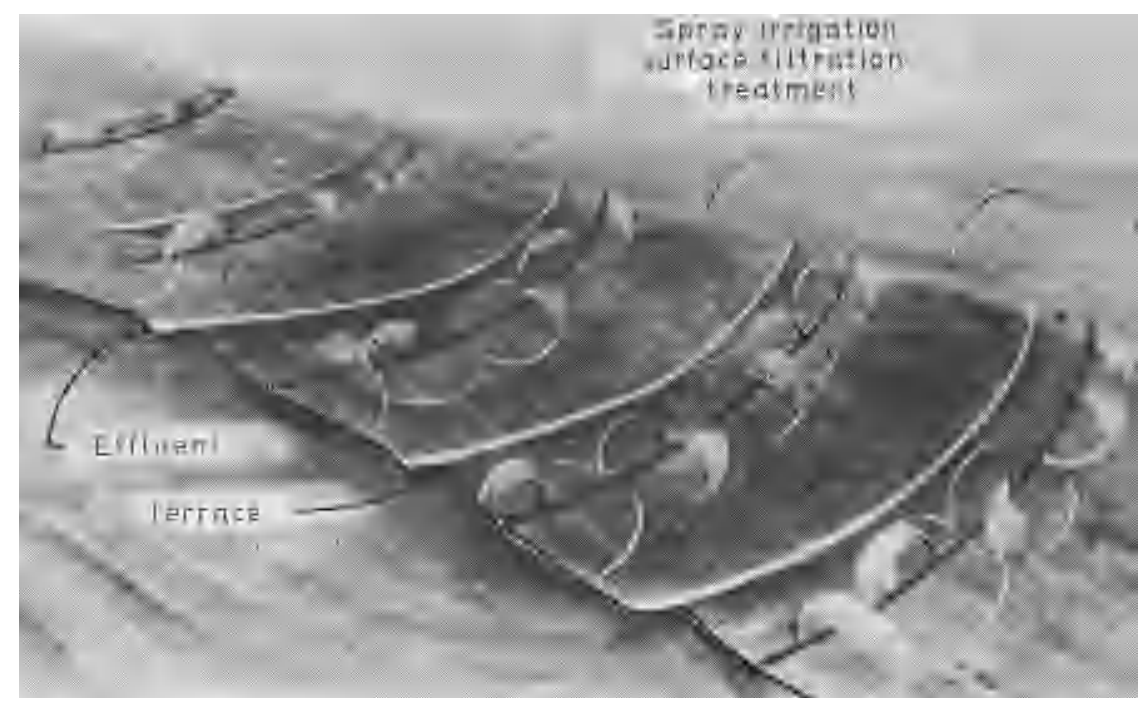

Figure 10. Spray irrigation surface filtration treatment.

waste water is applied approximately 0.6 inches per day, and flows across the land where it is purified in its travel downslope. The application is made from six to eight hours per day.

Detailed studies have shown that 175-foot lengths of slope will give effective purification. Basically the downslope area requirement is 50 feet beyond the perimeter of the sprinklers. The main purpose of these sprinklers is to apply the waste on the slopes in uniform applications. Any channelling reduces the efficiency of the system and the key to the entire programme is the thin sheet runoff in order to have a good inter-reaction zone with the soil 


\section{C. GILDE}

diurnal variations of electrical conductivity on the slope for each of the seasons of the year. The higher conductivity in the runoff during the summertime is due to the increase in evapotranspiration and the decrease in the volume of runoff. Analysis of ground water samples showed that while mineral salts had increased markedly over a five-year period of time, the total accumulation was not critical and there was some indication that the rate of increase might be less. Based on the data accumulated to date, no significant disturbance is anticipated to the soil structure for perhaps 35 to 50 years and an equilibrium stage due to rainfall will be reached sometime in the interim.

If a single terraced slope is accidentally overloaded or suffers a mechanical failure, the effluent treatment continues in the long terraces and waterways before the effluent reaches the receiving stream. In other words, a great deal of fail-safe capacity is built into the system.

The system is outstandingly successful even during the wintertime and sub-freezing weather during which ice has accumulated on the ground beneath the sprinklers. Until recent microbiological studies were made, the exact explanation for this was not known. It is a well-known fact that the respiration of microorganisms slows down as the temperature decreases. However, in the system as this occurs and as winter comes along, the numbers of organisms in the areas where the waste is applied increased many-fold over the decreased metabolism rate of the organisms present, therefore accounting for the excellent treatment. This is shown in Figure 12 where

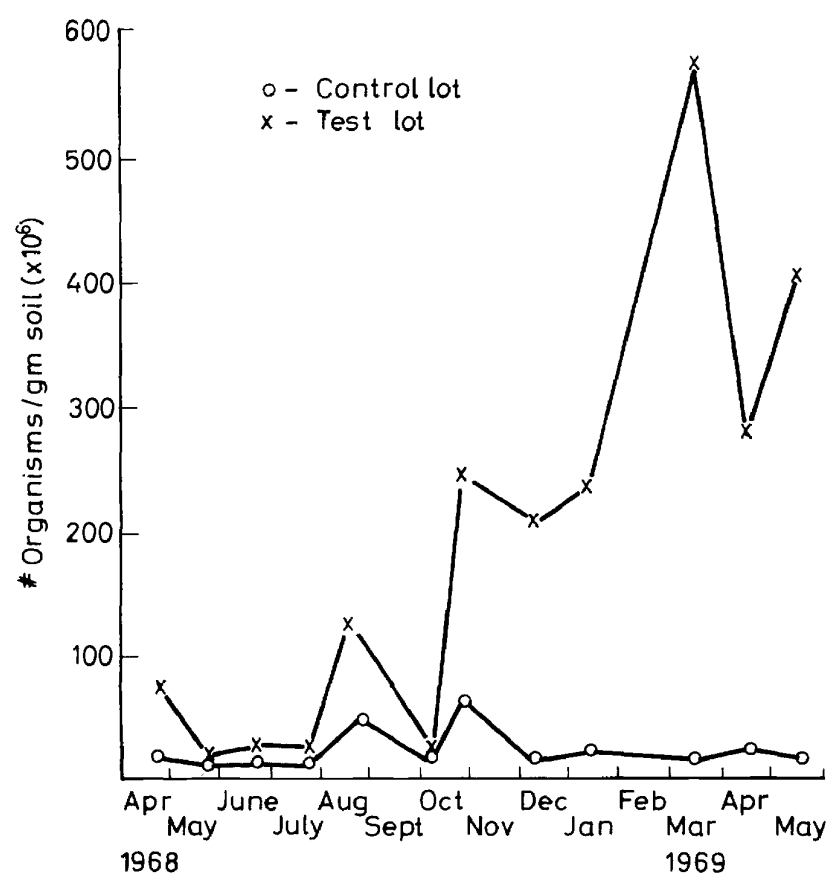

Figure 12. Total microbial population on controls and test lots. 
during the winter months the total number of organisms on the treatment areas exceeds by many times the total number of organisms in the control area.

The overland flow surface filtration technique has been developed to the point that an exceptionally high degree of waste purification has been demonstrated. The system at Paris, Texas has averaged in excess of 99 per cent reduction in BOD for over five years. Table 2 shows the efficiency of

Table 2. Treatment efficiency of the overland flow system

\begin{tabular}{lcccc}
\hline & \multicolumn{2}{c}{ Mean concentration, $\mathrm{mg} / 1$} & \multicolumn{2}{c}{ Per cent removal } \\
\cline { 2 - 5 } \multicolumn{1}{c}{ Parameter } & Waste water & $\begin{array}{c}\text { Section } \\
\text { effluent }\end{array}$ & $\begin{array}{c}\text { Concentration } \\
\text { basis }\end{array}$ & $\begin{array}{c}\text { Mass } \\
\text { basis }\end{array}$ \\
\hline Total suspended solids & 263 & 16 & 93.5 & 98.2 \\
Total organic carbon & 264 & 23 & 90.8 & -19.1 \\
$\begin{array}{l}\text { Biochemical oxygen demand } \\
\text { Total phosphorus }\end{array}$ & 616 & 9 & 98.5 & 61.5 \\
Total nitrogen & 7.6 & 4.3 & 42.5 & \\
& 17.4 & 2.8 & 83.9 & 91.5 \\
\hline
\end{tabular}

the system for one year. The BOD applied has averaged less than $10 \mathrm{ppm}$ BOD. This unique technique of treatment now extends the highly efficient performance to areas of impermeable soil where spray irrigation use was formerly considered impossible or impractical.

Another example of adapting waste treatment systems to the natural environment and geographical conditions is the poultry processing operation of Campbell Soup Company in Sumter, South Carolina. At this site, the soil had a high infiltration capability for the first five to seven feet and then a denser clay structure was encountered. The land was absolutely flat and any heavy dosage of waste would have created a quagmire or marsh. The entire field was under-drained at 200 -foot spacings with perforated pipe wrapped in fiber glass matting. This pipe conducted the drainage to a natural lagoon which is known locally as a Carolina Bay or savannah. This is shown diagrammatically in Figure 13. The concept of treatment was to have complete biological decomposition with the spray system and to follow up with a polishing pond. In actual operation, the infiltration rate of the sub-soil is sufficiently high as to keep the drainage to the lagoon at approximately ten to sixty per cent of the applied flow depending upon the season of the year and the amount of evapotranspiration. Of course, not all of the water is passed off to the atmosphere. A major portion of the water infiltrates into the ground because of the fact that the drainage field acts as a french drain system so that although in the immediate area of application the perforated pipe is quite active in carrying the water to the lagoon, the flow travels through so much unsaturated area it reinfiltrates into the sub-soil and therefore there is a water loss on the way to the lagoon.

This system has also been highly efficient. The sprays are laid out on a permanent underground system. There is no above-ground piping. The sprays are on a 120-foot triangular spacing. The application rate exceeds on some days one inch per day. The efficiency of the system is 99 per cent on a 


\section{C. GILDE}

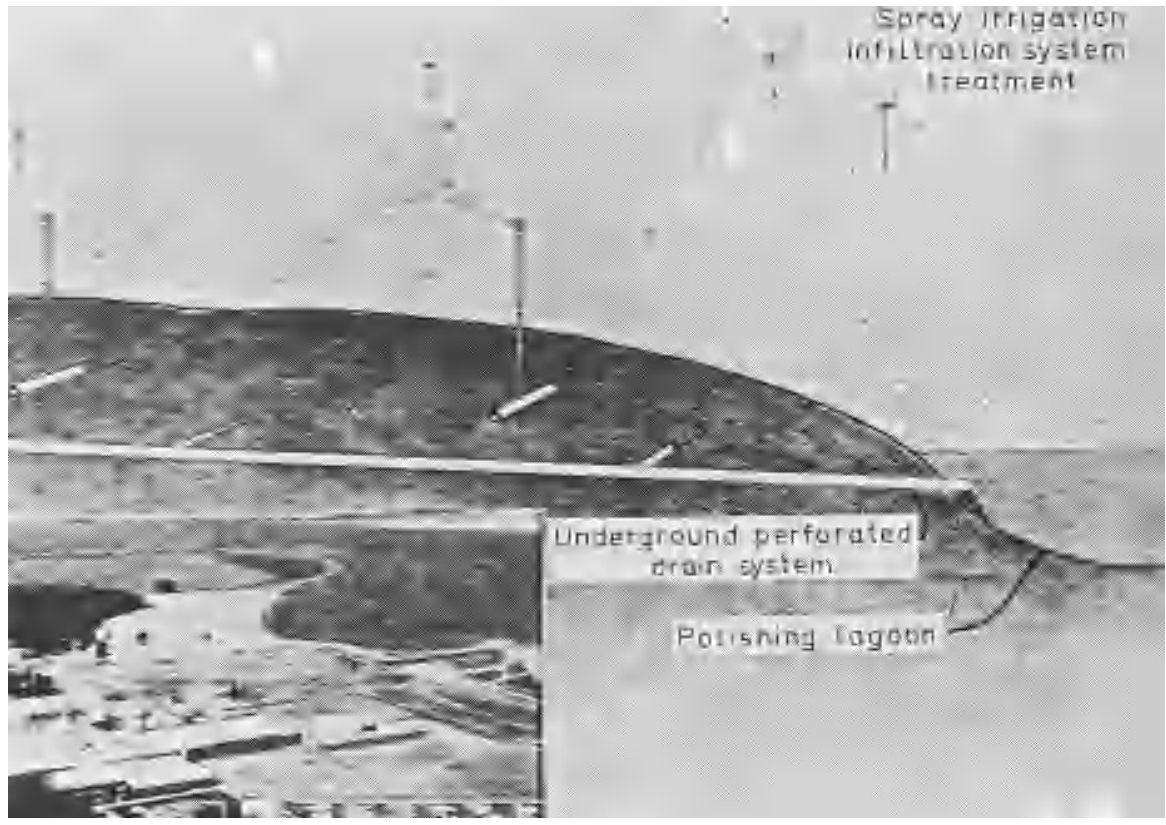

Figure 13. Spray irrigation infiltration system treatment.

total pound BOD removal basis. The efficiency on the effluent going to the lagoon is in excess of 95 per cent $\mathrm{BOD}$ reduction. The waste applied varies from 500 to $900 \mathrm{ppm}$ BOD with all samples of the effluent to the lagoon less than $10 \mathrm{ppm}$ BOD and the exfiltration from the lagoon to the receiving stream is approximately 5 ppm BOD.

This installation is an example of a waste treatment system enhancing the environment. The pond has become a wildlife sanctuary attracting all forms of waterfowl, ducks, egrets, blue heron, etc. On a single day, an ornithologist has identified fifty-two species of birds. The pond has a large number of large-mouth bass, bluegills, bream, and other fish. The receiving stream is still in its natural state harbouring all types of craytish, shrimp, and mussels, indicating a receiving water of extremely high quality.

\section{SOLIDS WASTE DISPOSAL}

The Abstract pointed out that the food processing industry is involved with the total environment from the farm to the consumer. This is abundantly clear when we take into consideration solid food waste, which includes the wastes produced in the growing and harvesting of raw crops, wastes produced in food processing, and wastes produced by the retailer and consumer. Interestingly, in some states - such as California-agriculture is by far the largest producer of solid waste. This is shown in Table 3, listing the categories of agricultural waste, industrial waste, and municipal waste. The tonnage of stalks, leaves, and cull foods left in the field or orchards far exceeds the 
Table 3. Production of total solid wastes-California, 1967*

\begin{tabular}{lc}
\hline Category of waste & $\begin{array}{c}\text { Amounts produced } \\
\text { (millions of tons) }\end{array}$ \\
\hline Agricultural wastes: & 21.8 \\
Animal manures & 2.4 \\
Fruit and nut crops & 10.7 \\
Field and row crops & \\
Industrial wastes & 2.1 \\
Food processing & 8.0 \\
Lumber industry & 0.5 \\
Chem. and petroleum & 3.1 \\
Manufacturing & \\
Municipal wastes: & 8.9 \\
Residential & 9.7 \\
Commercial & 3.0 \\
Demolition & 1.3 \\
Special & \\
$\quad$ Total of solid wastes & 71.5 \\
\hline
\end{tabular}

* From Industrial Solid Waste Production and Disposal in California. James Cornelius. California Vector Views. 16, No. 5; May (1969).

tonnage of harvested crops hauled to the market. Of course, the most significant of all farm wastes are the animal manures.

Studies by the National Canners Association have shown that to process 100 pounds of raw foods for the American housewife requires on the average that 36 pounds of waste materials be produced in the cannery. Again, on the average, 18 of the 36 pounds of waste are recovered as animal feed or byproducts. Of the 36 pounds of waste, ten pounds must be handled and disposed of as wet solid waste. The interesting factor here is that the canner's role in preserving raw foods is most important, for if this entire food processing were done by the housewife, instead of more than 50 per cent recovery

Table 4. Production of solid waste in the processing of each 100 pounds of selected foods

\begin{tabular}{lccc}
\hline Product & $\begin{array}{c}\text { Total waste } \\
\text { produced } \\
\text { (lbs) }\end{array}$ & $\begin{array}{c}\text { Utilized as } \\
\text { by-product } \\
\text { (lbs) }\end{array}$ & $\begin{array}{c}\text { Handled as } \\
\text { solid waste } \\
\text { (lbs) }\end{array}$ \\
\hline Apples & 30 & 20 & 10 \\
Beans, green & 20 & 9 & 11 \\
Beets, carrots & 53 & 30 & 23 \\
Citrus & 50 & 43 & 7 \\
Corn & 65 & 62 & 3 \\
Crab, shrimp & 72 & 8 & 64 \\
Fish & 36 & 22 & 2 \\
Olives & 14 & 12 & 22 \\
Peaches & 27 & 5 & 4 \\
Pears & 36 & 9 & 21 \\
Peas & 13 & 28 & 10 \\
Potatoes (white) & 49 & 21 & 19 \\
Tomatoes & 12 & 13 & 27 \\
Vegetables (misc.) & 32 & & \\
\hline
\end{tabular}


of waste as a by-product, the 36 pounds of solid waste would be discharged to the sewer or placed in the garbage can by the housewife, thus increasing the waste disposal problem.

It is apparent that we, in all solid waste disposal programmes, must recycle and find a greater amount of by-product recovery. Table 4 shows the production of solid waste in the processing of 100 pounds of various specific foods and the amount of by-product versus the final solid waste to be disposed of. Utilization of food processing waste as animal food is currently a widely used method for disposal of food processing solid waste. In some areas, the waste from seafood canning is pressed into fish meal for animal feed or into fertilizer material. Tomatoes have been pressed and dehydrated for use as dog food and cattle food. Pea vines, corncobs, and corn husks have also been used in the feed market area. Citrus peel waste may be pressed for molasses which may be processed, dried, and sold as cattle feed. Certain types of pits and nut shells have been converted to charcoal.

There are many areas in which food waste could be reused or somehow reclaimed, taking by-products into consideration. Among these are such things as production of alcohol from fruit wastes and composting of fruit waste solids. Looking at the matter practically, however, we find that the reclaiming of waste and by-products in some cases is as far away today as it was ten or twenty years ago because of economic factors. The simple fact of life is that in most cases it is much cheaper to dump, land fill, spread on the land, or discharge at sea rather than to attempt the more costly approaches of reclamation. One has to conclude that many social and economic factors are actively counter-current to technological attempts to reclaim wastes. With the competitive conditions of today's marketplace, there does not appear to be much chance of a change in the immediate future unless by legal restrictions or some form of subsidy the prevailing economic conditions can be altered.

With increased urbanization the problem is mounting. Increasing numbers of landfill operations are prohibiting or drastically limiting the inclusion of food processing waste solids. Because urbanization is taking up more and more land, in many cases the distances between potential sites for disposal or even areas of use of the food waste as animal feed are becoming more and more prohibitive because of transportation costs. Problems with animal feed from food wastes is the low protein content of the waste in many instances, and perhaps the major problem concerning disposal of all food waste is the timing. These operations are seasonal in nature, creating tremendous peaks during the late summer months completely disproportionate to actual need of possible by-product utilization. It is evident that thorough on-going research programmes are needed under the guidance of the best technical help. We are coming to the point in time when these problems may not be able to be handled as isolated individual cases but programmes will have to be looked at and solutions developed on a regional basis wherein community boundaries cannot isolate or thwart the progress of a unified overall approach to the resolution of solid waste disposal. It is evident that much research is required to come up with satisfactory solutions and there is a need for educational programmes for the general public to point out the long-range hazards of our present 


\section{MEASURES AGAINST WATER POLLUTION IN FOOD INDUSTRY}

solid waste disposal handling methods and the need to support more realistic programmes in the future to avoid reaching a crisis state. We cannot always expect by-product recovery to be a profitable programme and eventually in the future will have to be satisfied that even though there is a net cost to the industry, by-product utilization may be cheaper than other methods of disposal. The major capital costs inherent in by-product recovery may dictate the need for centralised recovery areas, especially for food processing operations of rather limited volume in order to make the programme economically feasible.

Our goal should be the elimination of transporting any waste solids in any form in the various steps from the farm to the processor to the consumer. Ideally, only perfect crops without culls, trims, or rejects should reach the food processor. In turn, the food processor should develop convenience foods in edible packages, thus eliminating solids disposal at the home.

In conclusion, we can solve our environmental problems only through a cooperative approach of water conservation, by-product recovery and processing revision. We must learn through a higher degree of efficiency proper management of our two major resources - food solids and water. An imaginative management can come up with innovations of in-plant control and treatment adapted to local conditions that are more economical than are most conventional treatment methods.

\section{ACKNOWLEDGEMENTS}

The author appreciates the helpful assistance of Mr. Walter Mercer of the National Canners Association for consultation, and, in particular, for providing slides which are represented as Figures 1 to 7 and Tables 3 and 4 in this paper.

\section{BIBLIOGRAPHY}

W. A. Mercer, Physical Characteristics of Recirculated Water as Related to Sanitary Conditions. Food Technology-(335) 77. March 1964.

W. A. Mercer, Water Reuse and Conservation. Presented at 9th Annual Short Course for the Food Industry. University of Florida. September 1969.

W. A. Mercer, Progress Toward Optimum Utilization of Water in Food Canning. Presented at Symposium, Innovations in Food Engineering. University of California, Berkeley, California March 1970.

W. A. Mercer, Statement on Solid Waste Disposal. Presented before the Sub-Committee on Air and Water Pollution of the Committee on Public Works, U.S Senate, Washington, D.C. February 1960.

G. A. Perkins, Case History in Food Plant Waste Water Conservation and Pretreatment Experience. National Symposium of Food Processing Wastes. FWPCA. Portland, Oregon. April 1970.

L. C. Gilde, Water Pollution Problems Facing the Food Industry. Princeton University Symposium, Princeton, New Jersey. March 1967.

L. C. Gilde, Experiences of Cannery and Poultry Waste Treatment Operations. 22nd Annual Purdue Industrial Waste Conference. May 1967.

L. C. Gilde, Poultry Processing Plant Waste Water Treatment System Enhances the Environment. ASME 1970 Annual Conference, Fort Worth, Texas. March 1970.

L. C. Gilde, Food Processing Waste Treatment by Surface Filtration. National Symposium on Food Processing Waste, FWPCA, Portland, Oregon. April 1970. 